\title{
TRANSFEKSI DNA KE DALAM MITOKONDRIA SEL BETA PANKREAS TIKUS DAN SEL PRIMER MYOBLAST MANUSIA: LANGKAH MENUJU REKAYASA DNA MITOKONDRIA DAN TERAPI GEN
}

\section{(DNA TRANSFECTION INTO CELLULAR MITOCHONDRIA OF MURINE $\beta$-PANCREAS AND HUMAN PRIMARY MYOBLAST CELLS: STEPS TOWARD GENETIC ENGINEERING OF mIDNA AND GENE THERAPY)}

\author{
Diana Lyrawati \\ Laboratorium Farmasi Fakultas Kedokteran Universitas Brawijaya
}

\begin{abstract}
The delivery of an exogenous or modified DNA into the mitochondria of mammalian cells has been proposed as an alternative way to prevent or modify mitochondrial genetic defect. In this study, a lipofection method was developed to transfer exogenous DNA into mitochondria of BRIN BD11 cells, a rat beta pancreas cell line, and human myoblast primary cells. An artificial mini-mitochondrial genome carrying a reporter gene encodes for a mitochondrial green fluorescent protein (mtGFP) was used to track the fate of the exogenous DNA following its transfection into cellular mitochondria. Epifluorescence microscopic observation was carried out to detect the green fluorescence resulted from the GFP expression. Immunohistochemical assays were also performed to validate and confirm the GFP expression. Collectively, the results indicate that the exogenous DNA pmtGFP could be delivered into the mitochondrial compartment and was functional within the mitochondria of BRIN BD11 and human myoblast cells. Such achievement is a significant progress as both the artificial DNA construct and the mitochondrial transfection method could serve as a model to study the dynamic of mutant mtDNA as well as to provide a basis for the development of gene therapy for human mitochondrial diseases.
\end{abstract}

Key words: DQAsome, pmtGFP, beta pancreas cell line, human myoblast primary cells

\section{PENDAHULUAN}

Introduksi DNA eksogen atau yang sudah dimodifikasi ke dalam mitokondria sel mamalia telah diajukan sebagai salah satu pilihan yang dapat digunakan untuk memanipulasi genom mitokondria (1). Prosedur tersebut dianggap sebagai metode yang potensial untuk membuat hybrid sitoplasma (cybrid) dan binatang model transmitokondria (1) dan dapat dikembangkan untuk pengiriman gen dan/atau terapi sel. Untuk mengevaluasi prosedur demikian, pada studi ini kami menggunakan transfeksi mitokondria dan konstruksi DNA pmtGFP (2) untuk memodifikasi mitokondria sel.

Pada penelitian ini digunakan metode transfeksi untuk memasukkan konstruksi DNA artifisial pmtGFP ke dalam mitokondria dalam sel utuh. Sebelumnya telah ditunjukkan bahwa dengan pendekatan tersebut ekspresi green fluorescent protein (GFP) dapat tercapai dalam mitokondria sel makrofag mencit (2). Tujuan penelitian ini adalah untuk mengetahui apakah sistem transfeksi dan pmtGFP yang mulanya dikembangkan dari dan untuk mitokondria sel mencit tersebut juga dapat diterapkan untuk mitokondria sel tikus dan manusia yang secara evousi mempunyai jarak divergens yang cukup jauh dengan mencit. Jika hal ini dapat tercapai, maka baik konstruksi DNA artifisialnya maupun metode transfeksi/pengirimannya ke dalam mitokondria sel akan dapat dikembangkan lebih lanjut sebagai model untuk mempelajari dinamika DNA mutan mitokondria maupun untuk

Jurnal Kedokteran Brawijaya, Vol. XX, No.3, Desember 2004

Korespondensi: Diana Lyrawati, Laboratorium Farmasi FK Unibraw,Jl. Veteran, Malang 65145. Fax 0341-564755; Tel 0341-

569117, 323676; E-mail : eldi_7_98@yahoo.com pengembangan terapi gen penyakit mitokondria pada manusia.

\section{METODE}

Kultur sel

Sel beta pankreas yang digunakan adalah sel BRIN BD11 passage 44 (pemberian Dr. Aris Wibudi, Institut Pertanian Bogor, Bogor, Indonesia). Sel BRIN BD 11 dikultur pada slide kultur 4 ruang (Chamber Slide Culture Chambers Permanox, Cat. No 1774371, Nunc) atau pada coverslips dalam $35 \mathrm{~mm}$ culture dishes (Nunc) dengan media kultur RPMI 1640 yang mengandung 10\% fetal bovine serum (FBS, Gibco), $100 \mathrm{IU} / \mathrm{mL}$ Penicillin (Gibco), $100 \mu \mathrm{g} / \mathrm{mL}$ Streptomycin (Gibco) dan $1 \mathrm{mM}$ L-glutamine (Gibco)

Sel myoblast yang digunakan adalah sel primer myoblast manusia individu normal passage 3-4 (pemberian Dr. Safarina Malik, Lembaga Biologi Molekuler Eijkman, Jakarta, Indonesia). Sel yang digunakan untuk transfeksi dikultur pada slide kultur 4 ruang atau pada coverslips dalam $35 \mathrm{~mm}$ culture dishes dengan media kultur HAM F-12 (Gibco, Invitrogen) yang mengandung $20 \%$ fetal bovine serum, $100 \mathrm{IU} / \mathrm{mL}$ Penicillin, $100 \mu \mathrm{g} / \mathrm{mL}$ Streptomycin dan $1 \mathrm{mM} \mathrm{L-glutamine.}$

Sel BRIN BD11 dan myoblast dikultur dalam inkubator bersuhu $37^{\circ} \mathrm{C}$ dengan atmosfir yang dilembabkan dan mengandung $\mathrm{CO}_{2} 5 \%$. Sel ditumbuhkan sampai mencapai konfluensi $\sim 75 \%$ kemudian digunakan untuk eksperimen transfeksi.

Transfeksi mitokondria sel BRIN BD11 dan sel primer myoblast manusia

Konstruk DNA yang digunakan untuk transfeksi mitokondria sel BRIN BD11 dan myoblast manusia adalah pmtGFP, sedangkan liposom yang digunakan adalah DQAsome. 
DQAsomes sebagai liposom untuk transfeksi mitokondria disiapkan sesuai dengan protokol yang telah dikemukakan sebelumnya (2). Secara singkat, dequalinium chloride (Sigma, Australia) konsentrasi akhir $10 \mathrm{mM}$ dilarutkan dalam methanol dalam tabung steril, kemudian pelarut organik diuapkan pada temperature ruang. Film tipis yang tersisa kemudian disuspensikan dalam air terdeionisasi, divortex dan disonikasi dalam sonikator penangas Branson selama 30 menit sampai diperoleh larutan opaque jernih. Larutan kemudian disentrifugasi pada 3000 rpm selama 30 menit dan supernatan yang diperoleh digunakan sebagai liposome untuk transfeksi. DQAsomes digunakan dalam 24 jam.

Transfeksi sel myoblast mnausia dilakukan dengan menambahkan $45 \mu \mathrm{L}$ lipoplex DQAsome (126 $\mu \mathrm{M}$ DQAsome, 138 ng pmtGFP) langsung ke dalam $1 \mathrm{~mL}$ media kultur. Sel diinkubasi selama 20 menit, kemudian media transfeksi diganti dengan media baru dan dikultur terus. Media kultur diganti tiap 2 hari. Sebagai kontrol, perlakuan yang sama diberikan kepada sel myoblast manusia, hanya saja lipopleks diganti DQAsome saja atau media kultur.

\section{Pengamatan mikroskopik epifluoresens}

Setelah transfeksi, fluoresensi hijau pada sel yang dikultur diamati secara periodik menggunakan mikroskop epifluoresens Axiophot (Zeiss, New York) yang dilengkapi dengan obyektif 100 $X$ dan filter GFP (eksitasi 470 excitation dan emisi $525 \mathrm{~nm}$ ). Gambar direkam dengan kamera manual kemudian diproses menggunakan Adobe Photoshop versi 7 (Adobe Systems Inc., Mountain View, CA).

\section{Immunohistokimia}

Sel BRIN BD11 dan myoblast manusia yang ditransfeksi lipopleks DQAsome-pmtGFP (hari ke 3-10 pasca-transfeksi) digunakan untuk percobaan imunohistokimia menggunakan antibodi monoklonal anti-GFP (mouse anti-GFP mAb, Sigma). Pewarnaan dilakukan menggunakan metode imunoperoksidase standar dan diaminobenzidin (Hofman, 1996). Sel yang terwarnai pada coverslips ditetesi Vectashield (Vector) kemudian ditempatkan pada slide. Ada tidaknya partikel berwarna coklat diamati secara mikroskopik (Axiophot microscope; Zeiss, New York).

Untuk mengkonfirmasi bahwa fluoresensi hijau yang teramati pada sel myoblast manusia yang ditransfeksi DQAsomepmtGFP memang berasal dari ekspresi GFP, eksperimen pengamatan mikroskopik epifluoresens dan pengecatan GFP secara imunokimia dilakukan secara simultan pada sel yang ditransfeksi DQAsome-pmtGFP. Sel yang ditransfeksi (hari ke 310 pasca-transfeksi) difiksasi dengan formaldehida $4 \%$ selama 20 menit dan setelah dicuci PBS selama 10 menit ditetesi Vectashield dan dipasang pada slide. Pengamatan fluoresensi hijau dilakukan dibawah mikroskop epifluoresens. Gambar sel yang menunjukkan fluoresensi hijau direkam menggunakan kamera mikroskop Zeiss dan posisi koordinatnya ditandai. Slide yang sama kemudian dicat secara imunokimia dengan antiGFP $\mathrm{mAb}$ seperti telah diterangkan sebelumnya. Sel yang terwarnai diamati secara mikroskopik dan gambar direkam dengan kamera mikroskop. Dengan menggunakan koordinat, gambar epifluoresens dan pewarnaan GFP dibandingkan untuk melihat kesesuaiannya.

\section{HASIL PENELITIAN}

\section{Sel BRIN BD11 dan myoblast manusia setelah transfeksi pmtGFP}

Setelah ditrasfeksi pmtGFP, sel BRIN BD 11 dan myoblast manusia dikultur lebih lanjut dan ekspresi GFP diamati dengan mikroskop epifluoresens. Pengamatan dilakukan pada hari ke 0 , 1, 3, 5, dan 10 pasca-transfeksi. Seperti pada sel makrofag mencit, sitotoksitas juga terjadi pada sel myoblast akibat liposome DQAsome yang digunakan untuk transfeksi. Pada 3 hari pertama pasca-transfeksi $\sim 80 \%$ sel mati. Sel transfektan yang dapat bertahan hidup ternyata mampu berproliferasi dan mencapai konfluen setelah hari ke 10.

Observasi fluoresensi dilakukan pada panjang gelombang GFP. Persentasi sel yang berfluoresensi hijau, positif GFP, berkisar antara $0-15 \%$ pada beberapa eksperimen yang berbeda, dengan rata-rata $1-5 \%$ (data tidak diperlihatkan). Sinyal fluoresensi terlihat pada sel yang ditransfeksi sebagai titik-titik fluoresensi hijau pada sitoplasma (Gambar 1 dan 2). Untuk mengkonfirmasi bahwa titiktitik yang berfluoresensi ini adalah hasil dari ekspresi GFP maka dilakukan uji imunohistokimia. Imunohistokimia dilakukan pada sel yang ditransfeksi pmtGFP menggunakan antibodi monoklonal anti-GFP dan visualisasi dilakukan menggunakan metode standar perokdidase. Titik titik berwarna coklat terlihat pada sel transfektan dan berkorelasi dengan hasil pengamatan fluoresensi (Gambar 1 dan 2). Data ko-lokalisasi ini, seperti yang terlihat pada Gambar 2, menunjukkan bahwa fluoresensi hijau pada sel transfektan merupakan hasil dari ekspresi pmtGFP. Dengan demikian metode transfeksi maupun konstruksi DNA pmtGFP yang awalnya dikembangkan untuk mitokondria sel mencit ternyata juga dapat diterapkan dan fungsional untuk mitokondria sel manusia.
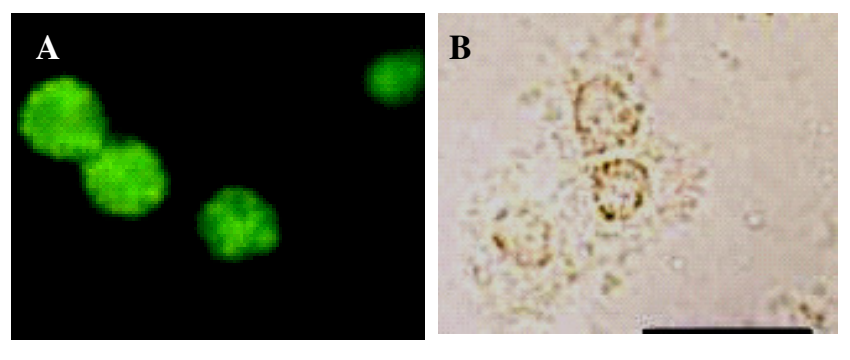

Gambar 1. Pengamatan fluoresensi hijau dan imunoreaktivitas terhadap anti-GFP pada sel BRIN BD11 yang ditransfeksi pmtGFP. Sinyal fluoresensi hijau (A) dan pewarnaan coklat hasil reaksi GFP-DAB (B) pada sel myoblast yang ditransfeksi DQAsome-pmtGFP. Pengamatan di atas dilakukan pada hari ke-5 pasca transfeksi dan gambar diambil dengan perbesaran 1250X 

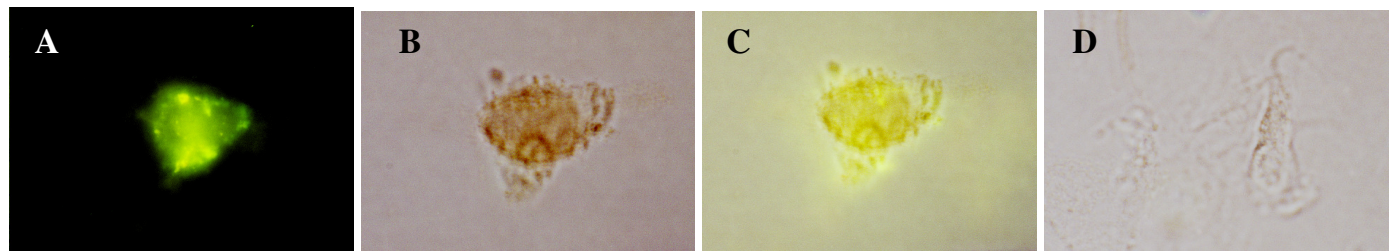

Gambar 2. Pengamatan fluoresensi hijau dan imunoreaktivitas terhadap anti-GFP pada sel myoblast manusia yang ditransfeksi pmtGFP. Sinyal fluoresensi hijau (A) dan reaksi GFP-DAB pada sel myoblast yang sama (B) serta setelah kedua gambar A dan B ditumpuk (C) menunjukkan bahwa kedua sinyal ter-ko-lokalisasi. Kontrol sel yang ditransfeksi DQAsome saja tidak menunjukkan pewarnaan coklat setelah reaksi imunohistokimia terhadap mAb anti-GFP (D). Gambar diambil dengan perbesaran 1250X.

\section{DISKUSI}

\section{Transfeksi pmtGFP}

Fluoresensi hijau yang terdeteksi setelah transfeksi mitokondria pada sel dari spesies yang berbeda, antara lain sel mencit RAW264.7 (2) dan sel beta pankreas tikus dan sel myoblast manusia (studi ini), menunjukkan bahwa pmtGFP dapat diekspresikan dan fungsional pada berbagai tipe sel mamalia. Hasil ini menyarankan bahwa faktor-faktor dan mekanisme yang diperlukan untuk transkripsi dan translasi mtgfp ada pada mitokondria sel dan memungkinkan terjadinya ekspresi mtgfp dengan benar. Hal ini sesuai dengan pengamatan pada berbagai penelitian xenomitokondria. Cybrid dan model binatang telah diproduksi menggunakan xenomitokondria dari spesies mamalia yang berbeda: sel mencit yang direpopulasi dengan mtDNA dari hamster (3) atau tikus (3-6), atau diinjeksi dengan mtDNA mutan manusia (7), juga sel manusia yang membawa mtDNA Pan (simpanse biasa atau pygmi) atau Gorilla (8) atau orangutan (9). Pada studi tersebut mtDNA donor secara aktif ditranskripsi, ditranslasi dan direplikasi dalam mitokondria sel resipien yang berbeda spesies, walaupun protein mitokondria yang dihasilkan tidak selalu fungsional pada proses oksidatif fosforilatif mitokondria. Yang menarik pada studi ini adalah nampaknya trans-acting factors mitokondria dari spesies yang berlainan dapat mengenali sekuens regulator pmtGFP yang diturunkan dari RAW264.7 mencit demikian juga gen mtgfp yang didesain untuk diekspresikan dalam sistem mitkondria mencit, sehingga pada akhirnya mtgfp dapat ditranskripsi. Selain itu, ekspresi mtgfp juga menyarankan bahwa native mitokondria dan/atau mtDNA dari berbagai sel mamalia dapat mengkomplementasi genom mitokondria artifisial pmtGFP. Komplementasi demikian sangat penting karena pmtGFP tidak memiliki hampir semua rRNA dan tRNA yang diperlukan untuk translasi mtgfp. Jadi, studi ini memberikan data tambahan yang mendukung ide bahwa mekanisme transkripsi dan translalsi mtDNA dan komplementasi mitokondria dipertahankan (conserved) pada mamalia, mulai dari mencit sampai manusia yang secara evolusi mempunyai jarak yang berjauhan sekali.

\section{Aplikasi genom mitokondria artifisial}

Telah banyak diketahui bahwa jumlah mtDNA tidak berkorelasi dengan jumlah mRNA dan polipeptida yang disandi mtDNA (10). Genom mitokondria artifisial yang menyandi gen reporter fungsional seperti pmtGFP atau penanda lain, dapat menjadi model untuk mempelajari pola ekspresi pada mitokondria dan kaitannya dengan mtDNA. Karena mitokondria mengalami fusi dan fisi, mungkin saja mtDNA dipertukarkan antar-mitokondria dengan kecepatan yang lebih rendah dibanding hasil transkrip maupun translasinya (11-13). Studi lokalisasi untuk melihat apakah distribusi pmtGFP parallel dengan ekspresi GFP akan membantu memperjelas konsep hubungan antara genotipefenotipe mitokondria. Pendekatan yang sama juga dapat digunakan untuk mengetahui efek batas ambang (threshold) yang berkaitan dengan mtDNA mutan, yaitu proporsi mutan tertentu yang harus tercapai sebelum ekspresi fenotipik dapat diamati (14). Dalam konteks penyakit mitokondria, variasi konstruk pmtGFP seperti penambahan gen mutan ke dalam pmtGFP atau mengganti gfp dengan gen lain akan dapat menjadi model yang lebih baik untuk dapat mengerti korelasi antara muatan mtDNA mutan dan manifestasi klinik.

\section{KESIMPULAN}

Pengembangan genom mitokondria artifisial yang fungsional dan metode transfeksi DQAsome untuk mengantar konstruk DNA tersebut dari luar ke dalam mitokondria yang berada di dalam sel utuh manusia, merupakan pendekatan yang penting dalam rekayasa mitokondria. Modifikasi dan optimasi protokol lebih lanjut akan dapat menghasilkan pendekatan atau metode baru untuk manipulasi mitokondria/genom mitokondria mamalia. Hal ini pada gilirannya akan memfasilitasi penelitian mengenai fungsi dan disfungsi mitokondria manusia dan penemuan strategi inovatif untuk terapi penyakit mitokondria.

\section{UCAPAN TERIMA KASIH}

Penulis menyampaikan terimakasih pada Dr. Aris Wibudi atas pemberian sel BRIN BD11, Drh. Safarina Malik, MS, PhD atas pemberian sel primer myoblast manusia dan, anti NDUFS1, dan Professor Sangkot Marzuki serta seluruh stafnya yang telah memperkenankan dan membantu penulis melakukan penelitian ini di Lembaga Eijkman, Jakarta. Penelitian ini dilaksanakan dengan biaya Dana SPP/DPP FK Unibraw (SPP-DPP/PEN/2005) dan bantuan Lembaga Biologi Molekular Eijkman-Jakarta a/n DL. 


\section{DAFTAR KEPUSTAKAAN}

1. Pinkert CA and Trounce IA. Production of transmitochondrial mice. Methods, 2002; 26: 348-357.

2. Lyrawati D, Trounson A and Cram D. (submitted) Expression of GFP In Mitochondrial Compartment Using DQAsome-mediated Delivery Of An Artificial Mini-mitochondrial Genome. Majalah Kedokteran Fakultas Kedokteran Universitas Brawijaya.

3. Yamaoka M, Mikami T, Ono T, Nakada K and Hayashi Jl. Mice With Only Rat mtDNA Are Required As Models Of Mitochondrial Diseases. Biochem Biophys Res Commun, 2001; 282: 707-711.

4. Yamaoka M, Isobe K, Shitara H, Yonekawa H, Miyabayashi S and Hayashi Jl. Complete repopulation Of Mouse Mitochondrial DNAless Cells With Rat Mitochondrial DNA restores Mitochondrial Translation But Not Mitochondrial Respiratory Function. Genetics, 2000; 155: 301-307.

5. Dey R, Barrientos A and Moraes CT. Functional Constraints Of Nuclear-Mitochondrial DNA Interactions In Xenomitochondrial Rodent Cell Lines. J Biol Chem, 2000; 275: 31520-31527.

6. McKenzie M and Trounce I. Expression Of Rattus Norvegicus mtDNA In Mus Musculus Cells Results In Multiple Respiratory Chain Defects. J. Biol. Chem., 2000; 275: 31514-31519.

7. Rinaudo P, Niven-Fairchild T, Buradagunta S, Massobrio M, Revelli A and Keefe DL. Microinjection Of Mitochondria Into Zygotes Creates A Model For Studying The Inheritance Of Mitochondrial DNA During Preimplantation Development. Fertility and Sterility, 1999; 71: 912-918.

8. Kenyon L and Moraes CT. Expanding The Functional Human Mitochondrial Dna Database By The Establishment Of Primate Xenomitochondrial Cybrids. Proc Natl Acad Sci USA, 1997; 94: 9131-9135.

9. Barrientos A, Muller S, Dey R, Wienberg J and Moraes CT. Cytochrome C Oxidase Assembly In Primates Is Sensitive To Small Evolutionary Variations In Amino Acid Sequence. Mol Biol Evol, 2000; 17: 1508-1519.

10. Tang Y, Schon EA, Wilichowski E, Vazquez-Memije ME, Davidson E and King MP. Rearrangements Of Human Mitochondrial DNA (mtDNA): New Insights Into The Regulation Of mtDNA copy Number And Gene Expression. Mol Biol Cell, 2000; 11: 1471-1485.

11. Azpiroz R and Butow RA. Mitochondrial Inheritance In Yeast. Methods Enzymol, 1995; 260: 453-465.

12. Nunnari J, Marshall WF, Straight A, Murray A, Sedat JW and Walter P. Mitochondrial Transmission During Mating In Saccharomyces Cerevisiae Is Determined By Mitochondrial Fusion And Fission And The Intramitochondrial Segregation Of Mitochondrial DNA. Mol Biol Cell, 1997; 8: 1233-1242.

13. Okamoto K, Perlman PS and Butow RA. The Sorting Of Mitochondrial DNA And Mitochondrial Proteins In Zygotes: Preferential Transmission Of Mitochondrial Dna To The Medial Bud. J Cell Biol, 1998; 142: 613-623.

14. Wallace DC. Mitochondrial Diseases In Man And Mouse. Science, 1999; 283: 1482-1488. 